\title{
THE LIFE OF THE POET
}

Beginning and Ending Poetic Careers

\section{Lawrence Lipking}

Through careful readings of those crucial poems in which poets find their identities, Lipking attempts to define patterns of development that all poets share. He discusses poets ranging from Virgil to Robert Lowell, emphasizing "not the biographies of poets but the biography

that gets into poems: the life that has passed through a refining poetic fire" (from the Preface).

Cloth $\$ 20.00264$ pages (est.)

\section{FOREIGNERS}

\section{The Making of American Literature, 1900-1940}

\section{Marcus Klein}

Klein argues that the significant literature of the modern period was the creation of persons who viewed themselves as marginal Americans, sometimes by an act of imagination and sometimes by birthright. "It is a good book, very well written. . . we must be grateful for something out of the ordinary in the way of explanations and evaluations." - Alfred Kazin Cloth $\$ 25.00 \quad 344$ pages

\section{DISSEMINATION}

\section{Jacques Derrida}

Translated by Barbara Johnson

In brilliant and original readings of Plato, Mallarmé, and Philippe Sollers, Derrida offers a major reevaluation of the logic of meaning and the function of writing in western discourse. Through the concrete practice of "deconstruction," he discovers and demonstrates a new reading of rhetoric and a new rhetoric of reading.

Cloth $\$ 22.50 \quad 448$ pages

\section{THE FAMILY IDIOT}

Gustave Flaubert, $1821-1857$

Jean-Paul Sartre

Translated by Carol Cosman

Volume 1

Sartre combines a psychoanalytic approach to Flaubert's personal development with a sociological study of the ideology of the period and the crisis in literature. The resulting work, complex and resistant to easy categorization, represents a kind of culmination of Sartrean thought, belief, and projet.

Cloth $\$ 25.00 \quad 624$ pages (est.)

\section{SARTRE AND FLAUBERT \\ Hazel E. Barnes}

In this first full-length study of The Family Idiot, Barnes evaluates both the biographer and his subject as they mutually illuminate one another. She offers a critical reappraisal of Madame Bovary based on her access to Sartre's own notes for an unpublished volume of The Family Idiot.

"It is a pleasure to read such a lucid, subtle, and generous book."- -Victor Brombert Cloth $\$ 25.00 \quad 464$ pages

\section{THE DECADENT IMAGINATION, 1880 - 1900 Jean Pierrot \\ Translated by Derek Coltman}

"Without being exhaustive, the work sees decadence in its totality across its foundations and its forms, especially in the domain of literature, thus constituting a remarkable contribution to our knowledge of a rich and exciting era."-Jean-Baptist Baronian, Histoire littéraire

Cloth $\$ 22.50$ (est.) 304 pages (est.)

\section{THE UNIVERSITY OF CHICAGO PRESS}




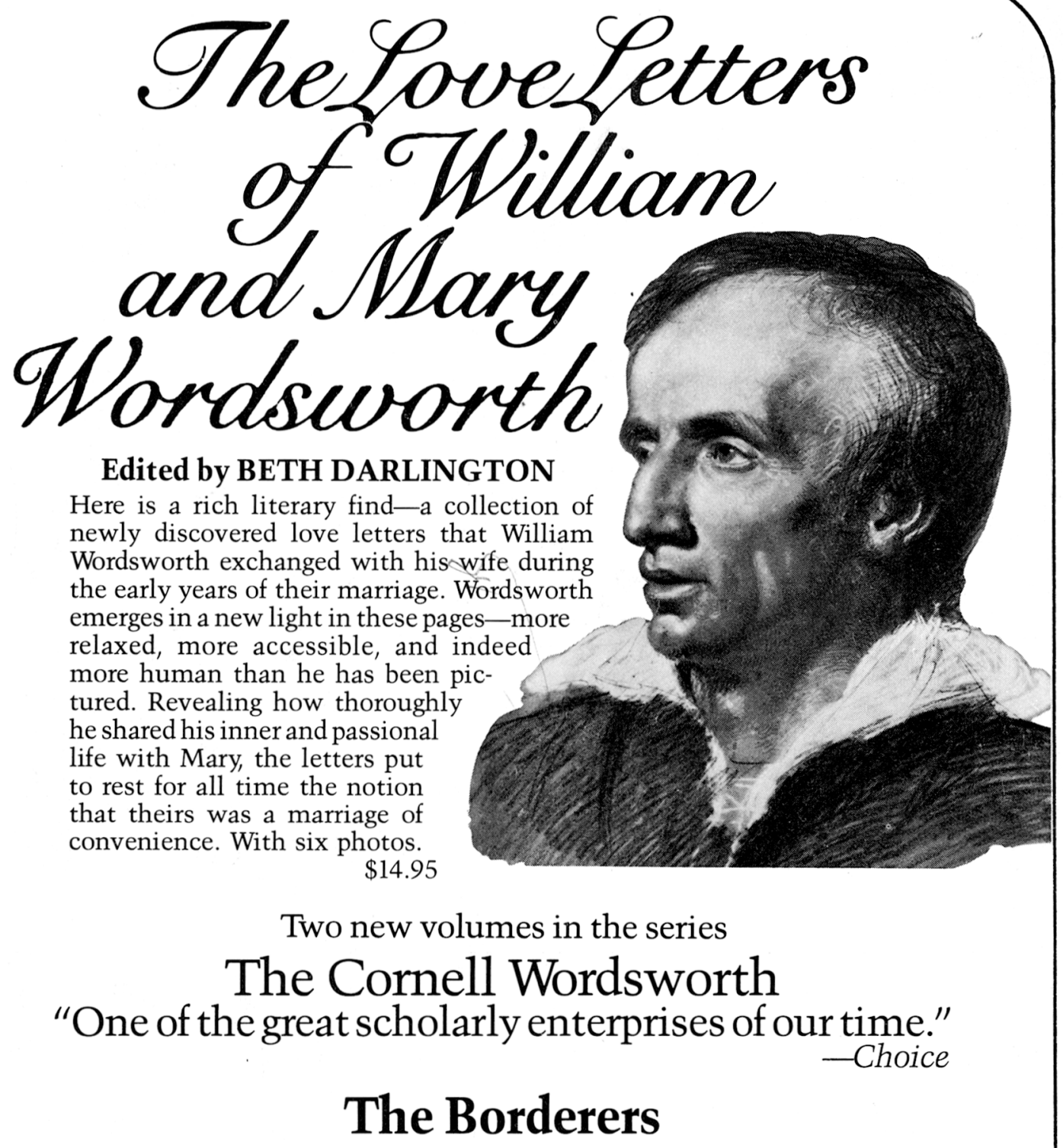

Edited by ROBERT OSBORN. This edition provides the reader with access to every stage in the textual history of Wordsworth's first major work. The appendixes present two poems associated with The Borderers - the fragmentary Gothic Tale and Argument for Suicide.

$\$ 75.00$

\section{Benjamin the Waggoner}

Edited by PAUL F. BETZ. Tracing the development of Wordsworth's poem, this edition presents for the first time complete texts of the two primary prepublication stages of the poem (1806 and 1812) and reprints the long-unavailable text of the 1819 first edition.

$\$ 39.50$

\section{CORNELL UNIVERSITY PRESS}

P.O. Box 250, Ithaca, New York 14850 